\title{
Economic impacts of partial harvesting: Mitigating mid-term timber supply shortages as a result of pest outbreaks
}

\author{
By Torben Jensen ${ }^{1}$ and Jean-Martin Lussier²
}

\begin{abstract}
Natural disturbances such as pest outbreaks have a significant impact on forest dynamics and services, including the loss of mature stands. From a wood production perspective, these disturbances can lead to long-lasting imbalances in the overall age-class structure of the forest, potentially resulting in a shortage of mature harvestable stands.

Researchers from Natural Resources Canada's (NRCan) Canadian Forest Service (CFS) have made a timber supply analysis of the Dunière forest located in the centre of the Gaspé Peninsula (Québec). This region suffers from an age-class structure imbalance caused by an eastern spruce budworm (ESB) outbreak that ended in 1984, and is consequently facing a reduced annual allowable cut, leading to long- term implications for the regional forest sector. The authors suggest that partial harvesting - the removal of a proportion of timber in a mature stand several years before a final cut is carried out - is a promising opportunity in the ESB-affected area for mitigating mid-term timber supply shortages by smoothing the fibre supply over time.
\end{abstract}

Keywords: age-class structure; eastern spruce budworm; Dunière forest, Gaspé Penninsula

\section{RÉSUMÉ}

Les perturbations naturelles comme les épidémies de ravageurs affectent grandement la dynamique forestière et les avantages que nous procurent les forêts, notamment par la perte de peuplements matures. Pour la production ligneuse, ces perturbations peuvent entraîner des déséquilibres prolongés dans la distribution générale des classes d’âge de la forêt qui pourrait se traduire par une raréfaction des peuplements matures à récolter.

Les chercheurs du Service canadien des forêts (SCF) de Ressources naturelles Canada (RNC) ont effectué un calcul de possibilité forestière pour la forêt de Dunière située au centre de la péninsule gaspésienne au Québec. Cette région présente un déséquilibre dans sa répartition des classes d'âge, en raison d'une épidémie de la tordeuse des bourgeons de l'épinette (TBE) qui a pris fin en 1984; elle doit alors composer avec une diminution de sa possibilité forestière qui aura des conséquences à long terme sur l'ensemble de l'industrie forestière de la région. Les auteurs avancent que la coupe partielle, soit la récolte d'une partie des tiges marchandes dans un peuplement mature plusieurs années avant sa coupe finale, constitue une avenue intéressante pour atténuer à moyen terme les pénuries de bois d'œuvre dans les secteurs perturbés par la TBE en adoucissant la courbe d'approvisionnement en fibre ligneuse.

Mots-clés: distribution des classes d'âge; tordeuse des bourgeons de l'épinette; forêt de Dunière, Péninsule gaspésienne

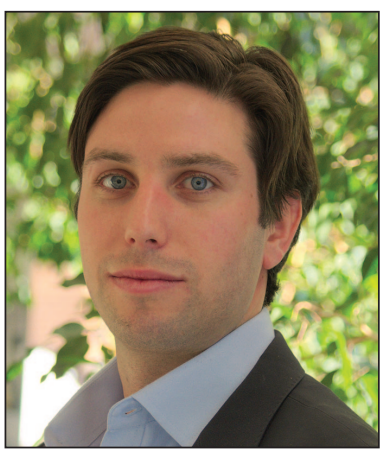

Torben Jensen

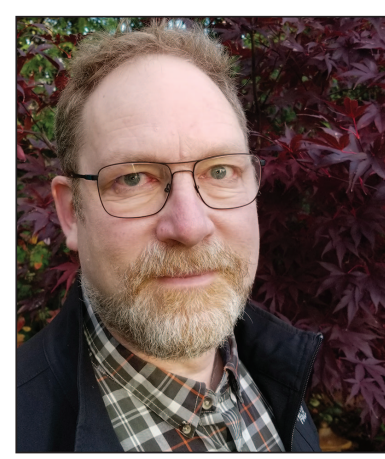

Jean-Martin Lussier

\section{Introduction}

Eastern spruce budworm outbreaks are cyclical natural forest disturbances that occur every 30 to 40 years. Outbreaks are common for a large portion of the eastern boreal forest and interior British Columbia, which are subject to severe periodical insect outbreaks. The eastern spruce budworm is found in every province and territory, but severely impacts forests in eastern Canada, with over 9.6 million hectares of forest in Québec having been affected as of 2019 (Gouvernement du Québec 2019). Stands that are 50 or more years-old are more vulnerable to eastern spruce budworm with tree mortality in affected areas ranging from $20 \%-100 \%{ }^{1}$. For wood produc-

${ }^{1}$ Dunière Forest Management Plan

\footnotetext{
${ }^{1}$ Canadian Forest Service, 580 Booth St., Ottawa, Ontario K1A 0E4, Canada, email: Torben.jensen@nrcan-rncan.gc.ca
}

${ }^{2}$ Laurentian Forestry Centre, 1055 Rue du Peps, Quebec City, QC, G1V 4C7, Canada 
tion, the loss of mature stands leads to a long-lasting imbalance in the overall age class structure of the forest, resulting in a shortage of mature harvestable stands. The timber supply in the Dunière forest has been particularly hard hit, with the majority of the region having been previously affected by an eastern spruce budworm outbreak ending in 1984 (Fig. 1).

The Dunière forest is approximately 60000 hectares, located in the center of the Gaspé Peninsula, privately owned by Investissement Québec and managed by Gestion Forestière Lacroix. The region is primarily composed of fir and spruce, has a planned allowable cut of $134000\left(\mathrm{~m}^{3}\right)$ per year for the next 25 years and primarily supplies the Temrex mill in the municipality of Nouvelle, Québec. ${ }^{1}$ The Dunière forest has very similar characteristics (age of stands, species mix, and eastern spruce budworm epidemics) as the Gaspé region as a whole, which is 1.7 million hectares, has an allowable cut of 1.36 million cubic metres per year and 13 local mills. ${ }^{2}$ Therefore, we expect results from this analysis of the Dunière forest may be extrapolated to cover the entire Gaspé region.

For the majority of forest management units in eastern Canada, the fibre supply and the allowable cut are determined by: (1) the age structure of the forest; (2) the growth rate of the existing and harvested forest; and, (3) sustainable forest management policies. Among the latter, the level of annual harvest is constrained to ensure a non-declining longterm timber production. In addition, measures are applied to protect biodiversity, particularly by maintaining a proportion of mature and old forests over time. Because of this policy, the possibility to clear-cut a significant proportion of mature stands is postponed until a later date. In the case of the
Dunière forest, researchers from Natural Resources Canada's Canadian Forest Service (CFS) suggest that the current age imbalance caused by eastern spruce budworm combined with the measures to maintain mature and old forests are the main factors limiting the allowable cut. As a result, the Dunière forest and Gaspé region lack mature forest stands which reduces the potential annual allowable cut, leading to long term implications for the regional forest sector.

\section{Research solution}

Partial harvesting $(\mathrm{PH})$, where a proportion of timber in a mature stand is harvested several years before a final cut is carried out, represents a promising opportunity for mitigating mid-term timber supply shortages in the eastern spruce budworm affected area by smoothing the fibre supply over time. The proposed solution is to partially harvest immature and mature stands during critical periods (where the availability of mature stands is limiting the timber supply), even if this means reducing the future potential harvestable volume at the stand level. Following long-term timber supply modeling, researchers suggest using $\mathrm{PH}$ in 60 to 80 year-old stands to increase the short-term timber supply. CFS researchers propose to $\mathrm{PH} 50 \%$ of the stand's harvestable volume, with a final clearcutting (CC) of the residual, or remaining, stand taking place later on. The timing and area of $\mathrm{PH}$ and final harvest is optimized to maximize timber production while complying with all the forest management objectives.

For the Dunière Forest, it was estimated that the timber supply could be increased by $8 \%$, without capping production $\operatorname{cost}^{3}$. At the landscape level, compared to CC, researchers estimate that $\mathrm{PH}$ could smooth the fluctuations

\footnotetext{
${ }^{1}$ Gestion Forestière Lacroix

${ }^{2}$ Plan d'aménagement forestière Gaspésie
}

${ }^{3}$ The increase was $3 \%$ at $\$ 45$ per $\mathrm{m}^{3}$; no increase was measured at $\$ 40$ per $\mathrm{m}^{3}$

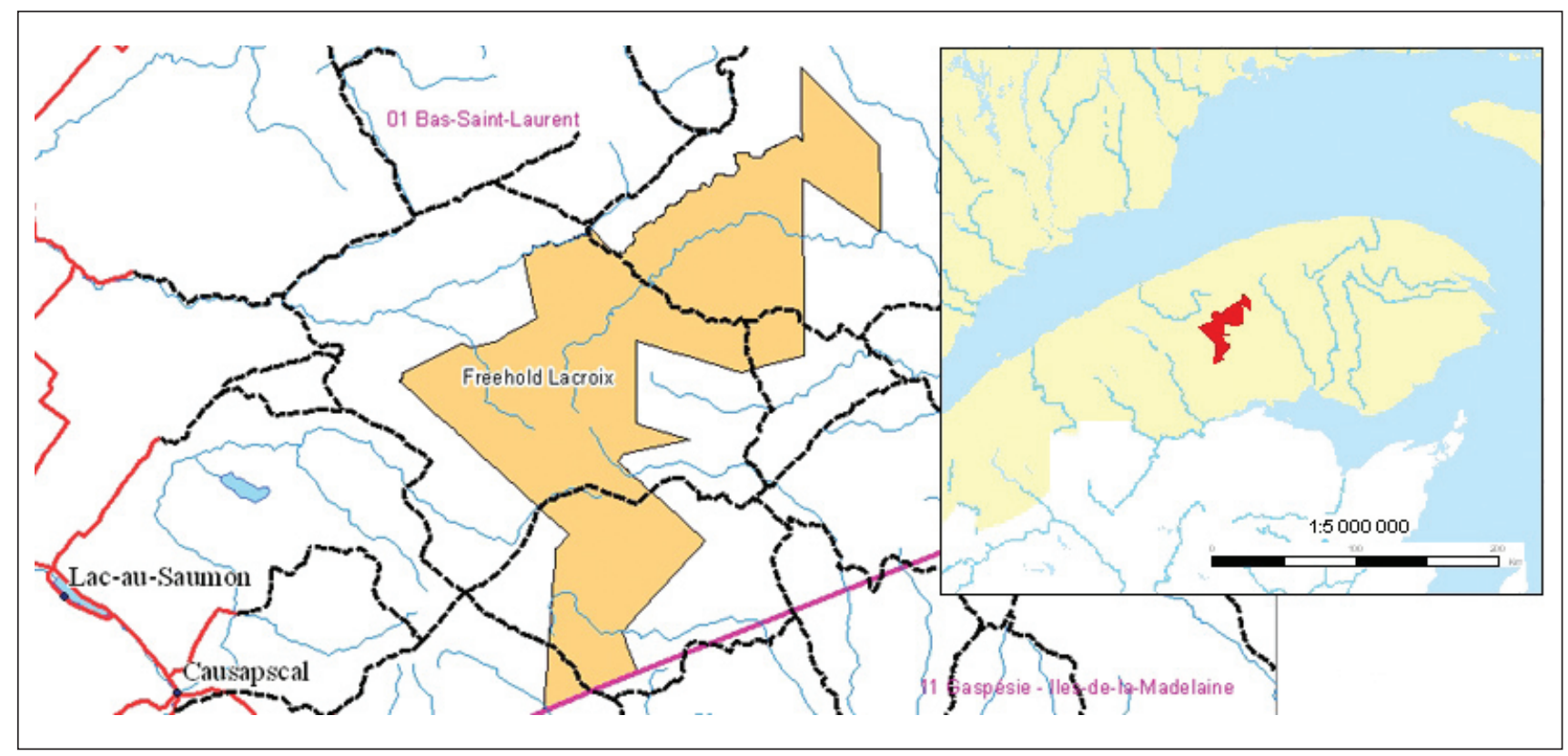

Fig. 1 Map of the Dunière forest, located in the center of the Gaspé Peninsula 
of available mature timber over time by allowing firms to harvest a portion of the volume of stand that are not considered ready for clearcutting (Spies and Griess 2018). Using a timber supply model, the evidence suggests $\mathrm{PH}$ should be considered in the development of policies to mitigate mid-term timber supply shortages. Nevertheless, to strengthen the case for this technique and others like it, understanding the economic benefit of this research project can further incentivise its implementation.

Clearcutting has been the norm in softwood-dominated woodlands since the industrialization of Canada's forest sector in the early $20^{\text {th }}$ century (Drushka 2005). This method was justified by a fast-growing demand for low-cost pulpwood and lumber, and was made possible with the technological advancements of mechanized harvest operations. In the 1980s, provincial regulations shifted to implement measures that ensured proper stand regeneration, which led to post-harvest plantation treatments, or to careful logging when natural advanced regeneration was available (Groot et al. 2005). Despite a growing interest for partial cutting silviculture in softwood forest (Ruel et al. 2007), its application remains limited, mostly because of higher operation and harvesting costs, and uncertainties around stand reaction to treatment (Bose et al. 2013).

\section{Results}

\section{Economic impact}

This project explores the economic viability of stand-level $\mathrm{PH}$ treatments to smooth the timber supply at the landscape level and the potential impact on the forest sector in the Dunière forest and the Gaspésie-Îles-de-la-Madeleine region of Québec. This report utilizes the outcomes from CFS researchers timber supply analysis, exploring the impacts of partial harvesting strategies on wood production from the Dunière forest (see annex for more information on the underlying scientific research). The economic analysis focuses on the profitability and socioeconomic impacts of the forest management strategies from the perspective of a simplified value chain, which includes the supply from the forest, the initial transformation at lumber mills and delivery to market. Through a cost-benefit analysis, which incorporates fixed costs (transportation and transformation), yields from the timber supply model, as well as profits and revenues derived from the market value of woodchips and lumber set at $\$ 64$ per green-tonne and \$510 per thousand board feet respectively ${ }^{4}$, we explore two scenarios over a 150 -year projection horizon:

Scenario 1: Assesses the control group (CC only, business as usual) to the influence of treatment (PH and CC). The $\mathrm{PH}+$ CC method increases annual allowable cut by $10600 \mathrm{~m}^{3}$ per year, resulting from greater access to fibre during critical periods through $\mathrm{PH}$. This is based on the outcomes from the CFS timber supply modeling.

\footnotetext{
${ }^{4}$ Source: $(2$ x 4 east SPF, kiln dried \#2 or better. Madison's 52 week avg, March 2020) and Risi - US Northeast Chip Prices Cad\$
}

Scenario 2: Same parameters as in Scenario 1, but assumes that the market price for woodchips falls to $\$ 0$ per tonne due to the lack of demand of chips in the region.

\section{Net present value}

When judging long-term investments, it is important to note that a dollar earned today is not worth the same as a dollar earned tomorrow, due to inflation, risk, and the opportunity cost of other potential investments. As such, a good metric to judge the profitability of an investment over time is the net present value. Net present value is the difference between the present value of cash inflows and the present value of cash outflows over a period of time, which provides a method for evaluating and comparing capital projects over time. To assess the influence of treatment $(\mathrm{PH}+\mathrm{CC})$ to the control group (CC only, business as usual) the net present value of each method was calculated over a 150-year time horizon (i.e., the simulation horizon of the timber supply model). In this study the cash flows (costs and revenues) (Hiesel et al. 2016) were discounted with an interest rate of $4 \%{ }^{5}$ and set to a base year $(=0)$.

Scenario 1 - Increased annual allowable cut for $\mathrm{PH}+\mathrm{CC}$ method In this $\mathrm{PH}+\mathrm{CC}$ scenario, a proportion of timber is harvested on average 20 years before a final residual cut is carried out. At the landscape level, this advances the timing of merchantable volumes during critical periods (current state), increasing the annual allowable cut in this case by 10 $600 \mathrm{~m}^{3}$ per year. The estimates used in this report find that over 150 years the harvesting, transportation and transformation costs for $\mathrm{PH}$ are on average $\$ 3.6$ per $\mathrm{m}^{3}$ more than $\mathrm{CC}$, mainly due to the lower productivity of the harvesting machines. As a result, average profits per $\mathrm{m}^{3}$ for $\mathrm{PH}$ are $\$ 3.8$ less per $\mathrm{m}^{3}$ than for CC.

Table 1. Assessment of the control group (CC only] to the influence of treatment (PH and $\mathrm{CC}$ )

\begin{tabular}{|c|c|c|c|c|}
\hline & \multicolumn{4}{|c|}{ Scenario 1} \\
\hline & \multicolumn{2}{|c|}{ First 25 years } & \multicolumn{2}{|c|}{150 years } \\
\hline & $\begin{array}{c}\text { Clear } \\
\text { cut }\end{array}$ & $\begin{array}{l}\text { Partial } \\
\text { harvest }\end{array}$ & $\begin{array}{c}\text { Clear } \\
\text { cut }\end{array}$ & $\begin{array}{l}\text { Partial } \\
\text { harvest }\end{array}$ \\
\hline $\begin{array}{l}\text { Merchantable } \\
\text { volume }\left(\mathrm{m}^{3}\right)\end{array}$ & $3.51 \mathrm{M}$ & $3.77 \mathrm{M}$ & $21.04 \mathrm{M}$ & $22.63 \mathrm{M}$ \\
\hline Chip volume (tonne) & $.51 \mathrm{M}$ & $.54 \mathrm{M}$ & $3.27 \mathrm{M}$ & $3.41 \mathrm{M}$ \\
\hline Lumber (mbf) & $.97 \mathrm{M}$ & $1.05 \mathrm{M}$ & $5.83 \mathrm{M}$ & $6.28 \mathrm{M}$ \\
\hline Revenue & $\$ 529 \mathrm{M}$ & $\$ 569 \mathrm{M}$ & $\$ 3182 \mathrm{M}$ & $\$ 3419 \mathrm{M}$ \\
\hline Costs & $\$ 315 \mathrm{M}$ & $\$ 348 \mathrm{M}$ & $\$ 1943 \mathrm{M}$ & $\$ 2171 \mathrm{M}$ \\
\hline Profit & $\$ 214 \mathrm{M}$ & $\$ 221 \mathrm{M}$ & $\$ 1239 \mathrm{M}$ & $\$ 1248 \mathrm{M}$ \\
\hline Net present value & $\$ 124 \mathrm{M}$ & $\$ 129 \mathrm{M}$ & $\$ 196 \mathrm{M}$ & $\$ 201 \mathrm{M}$ \\
\hline
\end{tabular}

${ }^{5} 4 \%$ discount rate based on the adopted recommendation of the USDA Forest Service in long-term resource planning 


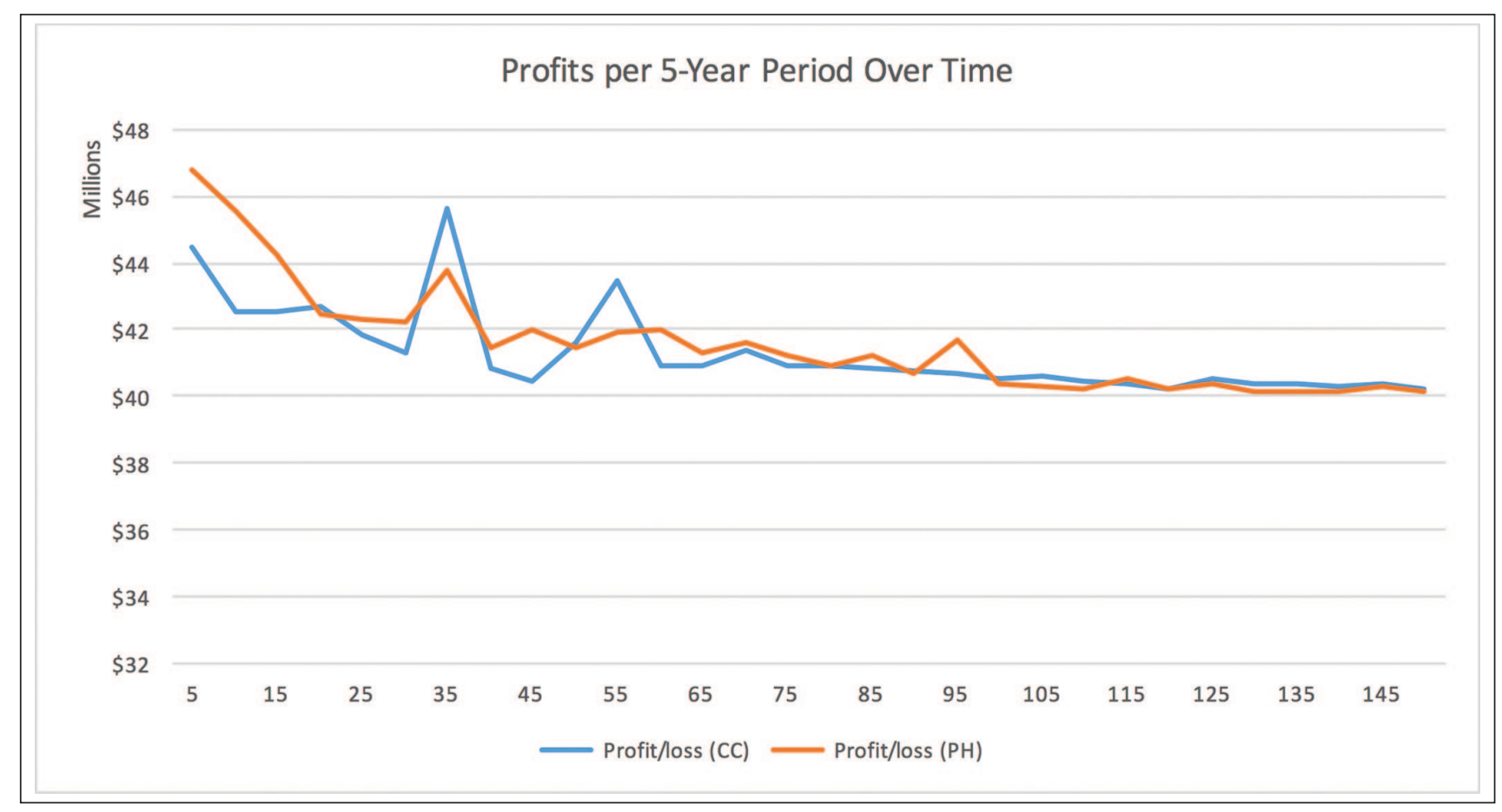

Fig. 2 Partial harvesting vs clear cutting profits over time

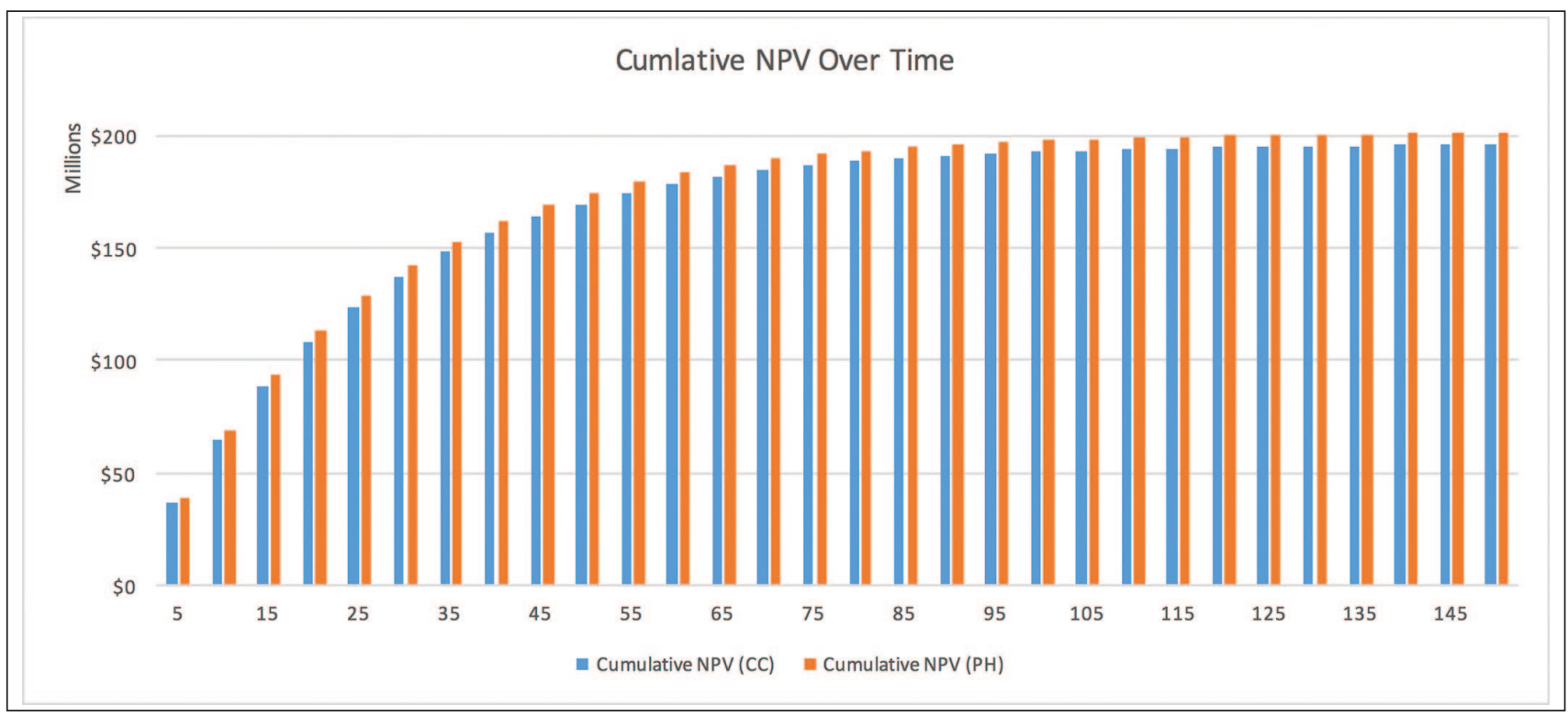

Fig. 3 Partial harvesting vs clear cutting cumulative net present value over time

By increasing the short-term timber supply, the majority of the benefits of $\mathrm{PH}$ come within the first 25 years (Table 1), as the goal of $\mathrm{PH}$ is to advance the timing of merchantable volumes during critical periods (current state). If $\mathrm{PH}$ were implemented in the Dunière forest today, undiscounted profits for $\mathrm{PH}$ would be about $\$ 7.2$ million more, a $3 \%$ increase (average of about $\$ 289000$ per year) than for CC over the first 25 years of this model. The same holds for longer time horizons even when considering higher costs, due to the increase in annual allowable cut undiscounted profits for $\mathrm{PH}$ are about $\$ 9$ million more, a $1 \%$ increase (average of about $\$ 60000$ per year) than for CC over the 150-year period (Fig. 2). As a result, $\mathrm{PH}$ significantly increases profits in the short run, while maintaining a stable and sustainable timber supply.

When applying the net present value methodology, the case for $\mathrm{PH}$ remains just as strong. When we take into account the increase in harvestable volume, net present value 
for $\mathrm{PH}$ is $\$ 5$ million higher, a 3\% increase over the 150 year projection horizon than it would have been had clear cutting continued to be the norm (Fig. 3). This presents a strong case for carrying out $\mathrm{PH}$ in the Dunière forest as well as for the entire Gaspé region.

\section{Scenario 2 - Woodchips are valued at \$0 per tonne}

Building on Scenario 1, we assume that the market price for woodchips falls to $\$ 0$ per tonne due to a lack of demand for chips in the region. $\mathrm{PH}$ gives foresters access to younger stands, as such it yields more chips per $\mathrm{m}^{3}$ then CC. Costs remain the same as in Scenario 1, however revenue, profits and net present value differ.

As discussed above, by increasing the short term timber supply the majority of benefits from $\mathrm{PH}$ come within the first 25 years as $\mathrm{PH}$ advances the timing of merchantable timber. As such, if $\mathrm{PH}$ were implemented in the Dunière forest today, even without a market for woodchips, undiscounted profits for $\mathrm{PH}$ would be about $\$ 5.7$ million more, a $3 \%$ increase (average of about $\$ 228000$ per year) than for $\mathrm{CC}$ over the first 25 years of this model. However, in this scenario, beyond 25 years $\mathrm{CC}$ is more profitable on average as undiscounted profits for $\mathrm{PH}$ are about \$225 000 less, relatively unchanged (average of about $\$ 1500$ per year) as compared to CC over the 150 year period (Table 2). $\mathrm{PH}$ realises a slightly higher share of profits from woodchips than CC, this scenario has shown that even when woodchips are set to $\$ 0$ per tonne, $\mathrm{PH}$ can still be an effective tool to increase the short-term timber supply while maintaining a consistent timbre supply in the long term.

When applying the net present value methodology, the case for $\mathrm{PH}$ remains just as strong. When we take into account the increase in harvestable volume, net present value for $\mathrm{PH}$ is $\$ 3.7$ million higher, a $2 \%$ increase over the 150 year projection horizon than it would have been had clearcutting continued to be the norm (Table 2). This presents a strong case for carrying out $\mathrm{PH}$ in the Dunière forest as well as for the entire Gaspé region even if woodchips are given away for free.

Table 2. Assuming chips have no value, assessment of the control group (CC only) to the influence of treatment (PH and CC)

\begin{tabular}{|c|c|c|c|c|}
\hline & \multicolumn{4}{|c|}{ Scenario 2 - No value for chips } \\
\hline & \multicolumn{2}{|c|}{ First 25 years } & \multicolumn{2}{|c|}{150 years } \\
\hline & $\begin{array}{c}\text { Clear } \\
\text { cut }\end{array}$ & $\begin{array}{l}\text { Partial } \\
\text { harvest }\end{array}$ & $\begin{array}{l}\text { Clear } \\
\text { cut }\end{array}$ & $\begin{array}{l}\text { Partial } \\
\text { harvest }\end{array}$ \\
\hline \multicolumn{5}{|l|}{ Merchantable } \\
\hline Volume $\left(\mathrm{m}^{3}\right)$ & $3.51 \mathrm{M}$ & $3.77 \mathrm{M}$ & $21.04 \mathrm{M}$ & $22.63 \mathrm{M}$ \\
\hline Chip Volume (ton) & $.51 \mathrm{M}$ & $.54 \mathrm{M}$ & $3.27 \mathrm{M}$ & $3.41 \mathrm{M}$ \\
\hline Lumber (mbf) & $.97 \mathrm{M}$ & $1.05 \mathrm{M}$ & $5.83 \mathrm{M}$ & $6.28 \mathrm{M}$ \\
\hline Revenue & $\$ 496 \mathrm{M}$ & $\$ 535 \mathrm{M}$ & $\$ 2973 \mathrm{M}$ & $\$ 3201 \mathrm{M}$ \\
\hline Costs & $\$ 315 \mathrm{M}$ & $\$ 348 \mathrm{M}$ & $\$ 1943 \mathrm{M}$ & $\$ 2171 \mathrm{M}$ \\
\hline Profit & $\$ 181 \mathrm{M}$ & $\$ 187 \mathrm{M}$ & $\$ 1030 \mathrm{M}$ & $\$ 1030 \mathrm{M}$ \\
\hline Net present value & $\$ 105 \mathrm{M}$ & $\$ 109 \mathrm{M}$ & $\$ 165 \mathrm{M}$ & $\$ 169 \mathrm{M}$ \\
\hline
\end{tabular}

\section{Socioeconomic impact}

To further evaluate the potential socioeconomic impacts of the additional fibre generated by $\mathrm{PH}$ as compared to $\mathrm{CC}$ per year, an input-output model ${ }^{6}$ was used which reports the effect based on multipliers for "Total Forest Operations". This model estimates that an increased average output in fibre supply of $10600 \mathrm{~m}^{3}$ per year could be used to produce 3 million board feet of lumber and 950 tonnes of chips per year with a market value of $\$ 1.58$ million. These increases in production are associated with an additional 11 jobs (five direct, three indirect, and three induced) and total GDP contributions of $\$ 1.1$ million ( $\$ 0.5 \mathrm{M}$ direct, $\$ 0.4 \mathrm{M}$ indirect, and $\$ 0.2 \mathrm{M}$ induced) per year. To put this into context, Québec's sawmills consumed an average of $146000 \mathrm{~m}^{3}$ of fibre per facility in 2018 (Delisle 2019). As a result, the additional 10 $600 \mathrm{~m}^{3}$ of fibre per year from $\mathrm{PH}$ in the Dunière forest is roughly equivalent to $7.3 \%$ of a sawmill's total input capacity. The increase in fibre supply from PH would help maintain the stability of the forest sector, providing local jobs and contributing the economy.

\section{Conclusion}

This analyses has shown that partial harvesting $(\mathrm{PH})$ has the potential to smooth the fibre supply, by increasing fibre availability during the critical periods when the age structure of forests is disrupted by natural disturbances such as pest outbreaks. The PH strategy also complies with current standards on ecologically sustainable forest management. As outlined in Scenario 1 above, our analysis demonstrates a higher return on investment for $\mathrm{PH}$ as net present value is \$5 million higher, a 3\% increase over the 150 year projection horizon than it would have been had clear cutting continued to be the norm. Finally, this model estimates that an increased average output in fibre of $10600 \mathrm{~m}^{3}$ per year with a market value of $\$ 1.58$ million from the $\mathrm{PH}$ method are associated with an additional 11 jobs and total GDP contributions of \$1.1 million for the local forest industry. The increase in fibre supply and higher returns from $\mathrm{PH}$ would help maintain the stability of the local forest sector industries, bringing countless intangible benefits to the regional forest sector. The benefits would be even greater if applied to the entire Gaspésie peninsula which has 28 times more hectares of forest than the Dunière region studied here.

\section{Discussion}

This analysis highlights the fact that $\mathrm{PH}$ techniques are effective at smoothing the fibre supply in regions where pest outbreaks have affected the age structure of forests. It is likely that pest outbreaks will change in intensity, severity and location, and so further research should be conducted to assess the economic viability of $\mathrm{PH}$ in other regions across the country. Good candidates to evaluate the viability of $\mathrm{PH}$ as means to smooth the timber supply, while addressing competitiveness issues include British Columbia, where the province's mature forests have been severely affected by the mountain pine beetle outbreak, and New Brunswick, which has had to manage several eastern spruce budworm outbreaks.

\footnotetext{
${ }^{6}$ Custom output tables provided by Statistics Canada
} 


\section{References}

Bose, A.K., B.D. Harvey, S. Brais, M. Beaudet and A. Leduc. 2013.

Constraints to partial cutting in the boreal forest of Canada in the context of natural disturbance-based management: A review. For. 87(1): 11-28. doi:10.1093/forestry/cpt047

Delisle, J-F. 2019. Portrait statistique. Ministère des Forêts, de la Faune et des Parcs du Québec.

Drushka, K. 2005. Canada's Forests: A History. McGill-Queen's University Press, Montreal, QC and Kingston, ON.

Gouvernement du Québec. 2019. Aires infestées par la tordeuse des bourgeons de l'épinette au Québec en 2019. Ministère des Forêts, de la Faune et des Parcs. Available from: https://mffp. gouv.qc.ca/forets/fimaq/insectes/fimaq-insectes-insectes-tordeuse.jpp [accessed 15 October 2020].

Groot, A., J-M. Lussier, A.K. Mitchell and D.A. MacIsaac. 2005. A silvicultural systems perspective on changing Canadian forestry practices. For. Chron. 81(1): 50-55.

Ruel, J-C., J-M. Lussier V. Roy and D. Pothier. 2007. Development of a silviculture adapted to the irregular boreal forest. For. Chron. 83(3): 367-374.

Spies, J. and V.C. Griess. 2018. Commercial thinning. A way to mitigate BC's midterm timber supply shortage. UBC Branchlines 28(1). 